\title{
7
}

\section{BOMBO, EL REAPARECIDO}

Mario Antonio Santucho

Buenos Aires: Seix Barral, 2019

208 pp. ISBN 978-950-731-976-1

Gerardo Helú

En julio del corriente año se cumplirán cincuenta años de la fundación del Ejército Revolucionario del Pueblo (ERP) anti-imperialista y revolucionario brazo armado del Partido Revolucionario de los Trabajadores (PRT); con su epílogo hacia julio de 1976, cuando su cúpula dirigente fue víctima del terrorismo de Estado, la historia de una de las organizaciones político-militares más trascendentes (junto con Montoneros) reaparece a través del libro del hijo de uno de sus principales dirigentes.

Mario Antonio Santucho nació en Buenos Aires en 1975 pero creció en Cuba. A los dieciocho años regresa a la Argentina y estudia Sociología en la Universidad de Buenos Aires. Dedicado a la investigación política, integró el Colectivo Situaciones, y actualmente es editor de la revista Crisis.

Situado en el verano tucumano del año dos mil trece, en Santa Lucía, el relato señala la fugaz reaparición de un hombre mayor que se identifica como el «Bombo» Ávalos. A partir de la sorpresa que causa la posibilidad de que el «Bombo» o «Teniente Armando» esté vivo, Santucho se sumerge en las condiciones políticas, 
sociales y económicas de nuestro país y del Tucumán azucarero de mediados de los sesenta, que fue sede de una de las organizaciones que fundaron el PRT (1965) y de la guerrilla rural, la Compañía de Monte «Ramón Rosa Jiménez».

El libro consta de ocho partes y un Epílogo. Las cuatro primeras relatan la vida de Julio Ricardo (Ávalos era el apellido de su progenitor, transformado en Abad por un presunto error burocrático) hasta su ingreso al PRT-ERP y su actuación en la guerrilla rural.

La salida de Tucumán, su viaje a la "gran ciudad» y su caída en las garras del terrorismo estatal son el eje de la narración de las partes V y VI (esta última, significativamente titulada «El limbo»), desde las que entronca con las dos últimas, dedicadas a un estrafalario personaje de la oligarquía tucumana devenido en escritor, y a la búsqueda del hermano menor del «Bombo», quien también participó de la guerrilla rural. El Epílogo plantea más interrogantes que certezas, respecto del tema del libro, la democracia, la violencia y la revolución (volveremos sobre él hacia el final de este escrito).

Con su oficio de científico social, Santucho recurre a fuentes tan diversas como la oralidad de combatientes del PRT-ERP, partes de guerra y entrevistas de «Estrella Roja» (órgano de prensa del ERP), escritos y testimonios de integrantes del aparato estatal terrorista y obras de ficción para construir un relato sobre las peripecias del personaje. Con la paciencia de un artesano, el autor indaga finamente en los diversos nombres del protagonista, en el que se articulan leyendas de heroísmo o posible traición, la burocracia y los intersticios del terrorismo estatal, así como la verosimilitud de los relatos literarios.

La narración se inicia en Tucumán, cuando lo que desde el título de la obra se plantea como certeza (la reaparición) es aquí, una duda (¿es posible que el Bombo viva?); así se rastrea la infancia de Julio Ricardo Abad en su Santa Lucía natal, la temprana muerte de su madre, la crisis del azúcar y la llegada de la eficiencia autoritaria del Onganiato para ordenar el cierre de los ingenios.

Allí su historia personal enlaza con el PRT-ERP, una de las organizaciones político-militares que pulularon en la América Latina pos-revolución cubana y que buscaban por diversas vías revolucionarias (que variaban desde formas de luchas rurales y urbanas, guevaristas o nacionalistas) el tránsito a una sociedad socialista o, en algunos casos, a un «socialismo nacional». La resistencia, las marchas, los enfrentamientos con la policía y las muertes convencen al «Bombo», 
sin experiencia sindical ni estudiantil, de que solo hay un camino y es la violencia revolucionaria del pueblo contra el ejército, la burguesía y el Estado opresor; por ello, se une al Partido.

En marzo del año 1974 inicia formalmente sus operaciones la Compañía de Monte «Ramón Rosa Jiménez», centrando sus acciones en la propaganda armada, las emboscadas, la toma de pequeñas localidades y el ejercicio de la justicia revolucionaria; casi un año después, comienza en Tucumán el «Operativo Independencia» que logrará diezmar a la guerrilla rural hacia los prolegómenos del golpe de estado de 1976.

Hasta allí, lo que se sabe del «Bombo»: lo que se presume será la incógnita que va a recorrer el resto de la narración, interrogante que pueden convertir al «Bombo» en héroe o traidor. Pero esa incógnita semeja a otros interrogantes que subyacen al libro y que no están enunciados en su título.

En el Epílogo, el autor confronta consigo mismo respecto de la elección del tema del libro: el PRT-ERP, la guerrilla rural, su padre desaparecido (que aparece lateralmente en el relato); en última instancia es la realidad que lo interpela, que lo hace reflexionar sobre el capitalismo y la desigualdad y lo proyecta hacia esperanzas revolucionarias.

Esa utopía revolucionaria que empujó la violencia organizada de los oprimidos para tomar el poder y crear una nueva sociedad, no parece hoy posible. Ahora bien, con la vuelta de la democracia liberal en nuestro país y en América Latina en los inicios de los años ochenta, la pobreza, la indigencia, la vulnerabilidad y la desigualdad, no solo no se esfumaron sino que, por el contrario, se agudizaron.

La pregunta que subyace, en todo caso, es si el verdadero personaje del escrito de Santucho son la rebelión y la revolución que, encarnadas en un anónimo tucumano, fueron desaparecidas en los setenta y pugnan por volver, renovadas en un proyecto emancipador que provoque fuertes rupturas, pero aún no encuentran el sujeto para canalizar la insurrección.

Este libro es una excelente puerta de entrada para un lector ávido de comenzar a profundizar en nuestra historia reciente, no solo por lo que se ha descrito previamente sino por las múltiples ramificaciones que la vida del «Bombo» proyecta sobre nuestro pasado, nuestro presente y fundamentalmente, nuestro futuro. 